\title{
PENGARUH TINGKAT PENDIDIKAN DAN JUMLAH PENDUDUK TERHADAP TINGKAT KEMISKINAN DI KOTA PEKANBARU
}

\author{
Herman \\ Sekolah Tinggi Ilmu Ekonomi Riau (STIER) \\ herman.2208@yahoo.com
}

\begin{abstract}
The purpose of this research is to see the effect of education level and population to poverty level in Pekanbaru city either partially or together. Population in this research Pekanbaru City 2011-2017. The data used in this study is secondary data obtained from the Central Bureau of Statistics (BPS) Pekanbaru city. While the method of analysis using multiple regression analysis techniques. The results showed that the level of education does not significantly affect the poor in Pekanbaru City. While the number of residents significant effect on the poor in Pekanbaru City while simultaneously variable education level and the number of residents significantly affect the poor in Pekanbaru City. The magnitude of influence is 94.1 percent.
\end{abstract}

Keywords: Education Level, Population, Poverty Level.

\begin{abstract}
Abstrak
Tujuan dari penelitian ini adalah untuk melihat pengaruh tingkat pendidikan dan jumlah pendudukterhadap tingkat kemiskinan di kotaPekanbaru baik secara parsial maupun bersama-sama. Populasi dalam penelitian ini Kota Pekanbaru 2011-2017. Data-data yang digunakan dalam penelitian ini adalah data sekunder yang diperoleh dari Badan Pusat Statistik (BPS) kota Pekanbaru. Sedangkan metode analisis menggunakan teknik analisis regresi berganda. Hasil penelitian menunjukkan bahwa tingkat pendidikan tidak berpengaruh signifikan terhadap penduduk miskin di Kota Pekanbaru. Sedangkan jumlah penduduk berpengaruh signifikan terhadap penduduk miskin di Kota Pekanbaru sedangkan secara simultan variabel tingkat pendidikan dan jumlah penduduk berpengaruh signifikan terhadap penduduk miskin di Kota Pekanbaru. Besarnya pengaruh adalah 94.1 persen.
\end{abstract}

Kata kunci: Tingkat Pendidikan, Jumlah Pnduduk, Tingkat Kemiskinan. 


\section{PENDAHULUAN}

Di beberapa negara berkembang, perhatian yang paling utama pada masalah pertumbuhan penduduk yang terus bertambah dan lapangan kerja sulit diperoleh oleh masyarakat, terutama yang memiliki tingkat pendidikan yang rendah bukan hanya itu permasalahan yang yang timbul yang baru ini adalah setiap tahunnya selalu ada masyarakat yang berbondong-bondong untuk melamar kerja, dimana tingkat pendidikan yang dimiliki setara dengan sarjana (S1), maka hal tersebut secara tidak langsung akan mengakibatkan tingkat pengangguran yang tinggi sehingga akan berdampak pada tingkat kemiskinan pada daerah/kota tersebut. Dari survei sosial ekonomi nasional (Susenas) yang dilakukan oleh badan pusat statistik setiap bulan Maret dan September menunjukkan pada periode 2011-2017 jumlah penduduk miskin menurun, yaitu dari 30,12 juta jiwa penduduk miskin (12,49 persen populasi) ditahun 2011, turun menjadi 27,77 juta orang penduduk miskin pada Maret 2017 (10,64 persen populasi). Kenaikan penduduk miskin terjadi pada September 2013 dan Maret 2015 karena pada periode tersebut terjadi kenaikan harga bahan pokok dan harga bahan minyak.

Masalah pendidikan dan perkembangan jumlah penduduk merupakan samasama penting namun sulit untuk diwujudkan secara bersamaan. Di kota Pekanbaru sendiri jumlah penduduk dari tahun 2011-2016 terus meningkat, yaitu pada tabel di bawah ini:

Tabel 1. Jumlah Penduduk

\begin{tabular}{ccc}
\hline No & Tahun & Jumlah Penduduk \\
\hline 1 & 2011 & 929.247 jiwa \\
2 & 2012 & 958.352 jiwa \\
3 & 2013 & 984.674 jiwa \\
4 & 2014 & 1.011 .467 jiwa \\
5 & 2015 & 1.038 .118 jiwa \\
6 & 2016 & 1.064 .566 jiwa \\
7 & 2017 & 1.091 .088 jiwa \\
\hline
\end{tabular}

Sumber : BPS Kota Pekanbaru
Bahwa dari tahun 2011 sebanyak 929.247 jiwa dan meningkat menjadi 1.091.088 jiwa pada tahun 2017. Rata-rata peningkatan yang terjadi adalah sebesar 26.974 jiwa. Dengan terjadinya peningkatan jumlah penduduk tiap tahunnya, maka akan berdampak pada pengeluran pemerintah dimama semakin besar jumlah penduduk, maka tingkat konsumsi masyarakat akan semakin bertambah sehingga harga/ kebutuhan pokok akan semakin langkah sehingga akan menimbulkan kenaikan harga dimana-mana sehingga masyarakat yang memiliki tingkat pendidikan yang masih rendah maka akan berdampak pada tingkat kemiskinan pada masyarakat tersebut. Dimana untuk tingkat pendidikan yang setara sarjana (S1) masih saja sulit untuk memperoleh pekerjaan. Berikut adalah gambaran tingkat pendidikan masyarakat kota Pekanbaru dari tahun 2011-2016, yaitu sebagai berikut :

Tabel 2. Persentase penduduk berumur 10 tahun ke atas menurut ijazah yang dimiliki

\begin{tabular}{lcccc}
\hline Pendidikan & $\mathbf{2 0 1 2}$ & $\mathbf{2 0 1 3}$ & $\mathbf{2 0 1 4}$ & $\mathbf{2 0 1 5}$ \\
\hline $\begin{array}{l}\text { Tidak } \\
\text { punya }\end{array}$ & 12.3 & 7,4 & 8,91 & 9,62 \\
ijazah & & & & \\
SD & 15,12 & 10,11 & 15,19 & 14,80 \\
SLTP & 18,33 & 17,48 & 16,84 & 18,45 \\
SLTA & 39,73 & 49,61 & 44,23 & 39,03 \\
Akademi & 4,45 & 3,79 & 3,69 & 4,77 \\
Univeritas & 10.07 & 11,61 & 11,14 & 13,33 \\
\hline
\end{tabular}

Sumber : BPS Kota Pekanbaru

Berdasarkan tabel di atas, dapat dijelaskan bahwa penduduk kota Pekanbaru untuk data tahun 2015 didominan oleh masyarakat dengan tingkat pendidikan SLTA, yaitu sebesar 39,03 persen sedangkan untuk tingkat pendidikan di Universitas pada tahun 2015 diperoleh bahwa sebanyak 13,33 persen sedangkan sisanya sebesar 86,67 persen lagi, maka hal tersebut dapat digambarkan bahwa 
tingkat pendidikan di kota Pekanbaru belum maksimal sehingga akan berdampak pada pengangguran yang akhirnya akan mengakibatkan timbulnya kemiskinan pada daerah/kota tersebut dimana pada jumlah penduduk miskin pada tahun terakhir yaitu tahun 2016 sebanyak 515,40 ribu jiwa dan pada tahun 2017 sebesar 514,62 ribu jiwa.

Berdasarkan permasalahan di atas, adapun tujuan dalam penelitian ini adalah untuk melihat seberapa besar pengaruh tingkat pendidikan dan jumlah penduduk terhadap tingkat kemiskinan pada kota Pekanbaru.

\section{Kemiskinan}

Secara harfiah, kemiskinan berasal dari kata dasar miskin yang artinya tidak berhartabenda. Dimana kemiskinan adalah kondisi dimana secara ekonomi yang berarti orang yang sangat kekurangan. Kondisi ketidakmampuan ini ditandai dengan rendahnya kemampuan pendapatan untuk memenuhi kebutuhan pokok baik berupa pangan, sandang, maupun papan. Kemampuan pendapatan yang rendah ini juga akan berdampak berkurangnya kemampuan untuk memenuhi standar hidup rata-rata seperti standar kesehatan masyarakat dan standar pendidikan.

Pengertian kemiskinan yang saat ini populer dijadikan studi pembangunan adalah kemiskinan yang seringkali dijumpai di negara-negara berkembang dan Negara dunia ketiga. Persoalan kemiskinan masyarakat di negara-negara ini tidak hanya sekedar bentuk ketidakmampuan pendapatan, akan tetapi telah meluas pada bentuk ketidakberdayaan secara sosial maupun politik (Suryawati, 2004).

(Dandekar, 1982; Mehta, 1982; Sukhatme, 1982) mengungkapkan seolaholah kemiskinan merupakan suatu konsep yang bersifat relatif, masyarakat miskin adalah mereka yang berpenghasilan jauh kurang dari pada yang lebih baik.
Menurut Bank Dunia, kemiskinan merupakan kekurangan dalam kesejahteraan, yang terdiri dari banyak dimensi. Badan Pusat Statistik mendefinisikan kemiskinan sebagai individu yang mempunyai rata-rata pengeluaran per bulan kurang dari garis kemiskinan. Garis kemiskinan adalah penjumlahan antara garis kemiskinan makanan dan garis kemiskinan non makanan. Garis kemiskinan makanan adalah garis kemiskinan yang mengacu pada pengeluaran individu dalam memenuhi kebutuhan minimum makanannya sebanyak 2.100 kalori per kapita per hari, sedangkan garis kemiskinan non makanan mengacu pada pengeluaran individu dalam memenuhi kebutuhan minimum non makanan, seperti perumahan, sandang, pendidikan dan kesehatan (Hakim, 2006).

Menurut SMERU Research Institute, kemiskinan didefinisikan dengan melihat berbagai dimensi yaitu (Hamid, 2008):

1) Ketidakmampuan dalam mencukupi kebutuhan pokok (sandang, pangan dan papan).

2) Tidak mempunyai akses terhadap kebutuhan dasar lainnya seperti kesehatan, pendidikan, sanitasi, air bersih, dan transportasi.

3) Tidak mempunyai jaminan atas masa depan yang disebabkan tidak adanya investasi pendidikan dan keluarga.

4) Rentan terhadap masalah yang bersifat individual maupun massal.

5) Mempunyai kualitas sumber daya manusia yang rendah dan sumber daya alam yang terbatas.

6) Tidak pernah ikut dalam kegiatan sosial di masyarakat.

7) Tidak mempunyai akses terhadap kesempatan kerja dan pekerjaan yang mapan.

8) Tidak mampu berusaha karena mempunyai kelainan fisik maupun mental .

9) Ketidakmampuan sosial seperti anakanak terlantar, wanita korban kekerasan rumah tangga, janda miskin, kelompok minoritas dan terpencil. 
Menurut BPS, kemiskinan pada dasarnya bisa dilihat dari dua sisi, yaitu:

1) Kemiskinan Absolut

Kemiskinan absolut adalah kemiskinan yang berkaitan dengan tingkat pendapatan dan kebutuhan yang terbatas pada kebutuhan pokok sehingga orang tersebut dapat disebut hidup dengan layak.

2) Kemiskinan Relatif

Kemiskinan relatif dilihat dari aspek ketimpangan sosial. Apabila seseorang sudah mampu memenuhi kebutuhan dasar minimumnya, namun masih jauh lebih rendah bila dibandingkan dengan masyarakat di sekitarnya, maka orang tersebut termasuk kategori miskin relative.

Kemiskinan berkaitan dengan lapangan pekerjaan dan biasanya penduduk yang dikategorikan miskin tidak memiliki pekerjaan, serta tingkat pendidikan dan kesehatan yang pada umumnya tidak memadai karena sempitnya lapangan pekerjaan dan besarnya jumlah penduduk.

Berdasarkan definisi-definisi di atas, maka dapat disimpulkan bahwa kemiskinan adalah kondisi seseorang yang tidak mampu mencukupi kebutuhan dasarnya.

\section{Penyebab Kemiskinan}

BPS menyebutkan bahwa berdasarkan penyebabnya, kemiskinan terbagi menjadi 2 yaitu:

1) Kemiskinan kultural, yaitu kemiskinan yang disebabkan karena faktor-faktor adat atau budaya dari suatu daerah yang menyebabkan seseorang tetap berada dalam kemiskinannya.

2) Kemiskinan struktural, yaitu kemiskinan yang disebabkan karena ketidakberdayaan seseorang pada tatanan sosial yang kurang adil.

\section{Ukuran Kemiskinan}

BPS menggunakan pendekatan kebutuhan dasar sebagai indikator kemiskinan, yaitu:
1) Head count index, yaitu persentase penduduk yang berada di bawah garis kemiskinan.

2) Poverty gap index, yaitu ukuran rata-rata kesenjangan pengeluaran masing-masing penduduk miskin terhadap garis kemiskinan.

3) Poverty severity index, yang memberikan gambaran mengenai penyebaran pengeluaran diantara penduduk miskin.

\section{Tingkat Pendidikan}

Pengetahuan adalah hasil tahu dari seseorang setelah menggunakan panca indera baik itu indra penglihatan, pendengaran, penciuman, perabaan terhadap suatu objek (Notoatmodjo, 2010).

Menurut Andrew E. Sikula dalam Mangkunegara tingkat pendidikan adalah suatu proses jangka panjang yang menggunakan prosedur sistematis dan terorganisir, yang mana tenaga kerja manajerial mempelajari pengetahuan konseptual dan teoritis untuk tujuan-tujuan umum.

Menurut UU RI No. 20 Tahun 2003 pasal 1, pada dasarnya jenjang pendidikan adalah tahapan pendidikan yang ditetapkan berdasarkan tingkat perkembangan peserta didik, tujuan yang akan dicapai, dan kemampuan yang dikembangkan.

Tingkat Pendidikan adalah suatu kondisi jenjang pendidikan yang dimiliki oleh seseorang melalui pendidikan formal yang dipakai oleh pemerintah serta disahkan oleh departemen pendidikan. Dikategorikan menjadi: Tidak pernah sekolah, SD sampai SMP, SMU, Perguruan Tinggi (Andy, 2012: http;//fourseasonnew.blogspot.com).

Untuk mencapai tujuan tersebut, pendidikan diselenggarakan melalui jalur pendidikan sekolah (pendidikan formal) dan jalur pendidikan luar sekolah (pendidikan non formal). Jalur pendidikan sekolah (pendidikan formal) terdapat jenjang pendidikan sekolah, jenjang pendidikan sekolah pada dasarnya terdiri dari pendidikan prasekolah, 
pendidikan dasar, pendidikan menengah, dan pendidikan tinggi.

Menurut Nata (2001:98) pendidikan adalah bimbingan atau arahan secara sadar oleh si pendidik terhadap perkembangan jasmani dan rohani terdidik menuju terbentuknya kepribadian yang utama.

\section{Dimensi Tingkat Pendidikan}

Menurut Tirtarahardja (2005:53), Dimensi tingkat pendidikan terdiri dari:

Menurut Tirtarahardja (2005:53), Dimensi tingkat pendidikan terdiri dari:

1. Jenjang pendidikan

Jenjang pendidikan adalah tahapan pendidikan yang ditetapkan berdasarkan tingkat perkembangan peseta didik, tujuan yang akan dicapai dan kemampuan yang dikembangkan.

2. Kesesuaian jurusan

Kesesuaian jurusan adalah sebelum pegawai direkrut terlebih dahulu perusahaan menganalisis tingkat pendidikan dan kesesuian jurusan pendidikan pegawai tersebut agar nantinya dapat ditempatkan pada posisi jabatan yang sesuai dengan kualifikasi pendidikannya.

3. Kompetensi

Kompetensi adalah pengetahuan, penguasaan terhadap tugas, keterampilan dan nilai-nilai dasar yang direfleksikan dalam kebiasaan berfikir dan bertindak

\section{Jumlah Penduduk}

Definisi dari penduduk adalah warga negara Indonesia maupun warga negara asing yang bertempat (berdomisili) di Indonesia. Penjabatan dari pembahasan mengenai kependudukan ini mencakup jumlah, umur, struktur, persebaran, mobilitas, dan kualitas serta ketahanannya yang berkaitan dengan sektor politik, sosial, budaya, dan ekonomi.

Penduduk adalah orang dalam matranya sebagai pribadi, anggota keluarga, anggota masyarakat, warga negara dan himpunan kuantitas yang bertempat tinggal di suatu tempat dalam batas wilayah tertentu (Mantra, 2009). Pertumbuhan penduduk merupakan keseimbangan yang dinamis antara kekuatan-kekuatan yang menambah dan kekuatan-kekuatan yang mengurangi jumlah penduduk. Secara terus menerus penduduk di suatu wilayah dipengaruhi oleh besarnya kelahiran (fertilitas), kematian (mortalitas), in-migration (migrasi masuk) dan out-migration (migrasi keluar). Besar kecilnya laju pertambahan penduduk disuatu wilayah sangat dipengaruhi oleh besar kecilnya komponen pertumbuhan penduduk.

Menurut aliran Malthusin terjadi ketidakseimbangan antara pertumbuhan penduduk berjalan berdasarkan deret ukur, sedangkan pertumbuhan/pertambahan makanan berdasarkan deret hitung. Oleh karena itu, pertumbuhan penduduk harus dibatasi. Pembatasan jumlah penduduk dapat dilakukan dua cara yaitu preventive dan positive check.

Peran kepadatan penduduk dan modal manusia dalam meningkatkan pertumbuhan ekonomi berasal dari positif spillovers yang ditimbulkan oleh pendidikan dan pelatihan (Storper dan Venables, 2004). Di daerah yang padat penduduk, penyebaran pengetahuan akan lebih cepat terjadi karena penduduk lebih sering berinteraksi satu sama lain. Interaksi yang terjadi antara penduduk dengan akumulasi modal manusia yang tinggi akan menimbulkan inovasi-inovasi baru yang akhirnya akan meningkatkan produktivitas. Kepadatan penduduk disertai dengan akumulasi modal manusia yang tinggi akan mendorong peningkatan aktivitas ekonomi. Keahlian dan pengetahuan yang dimiliki individu akan mempengaruhi kinerjanya. Orang-orang dengan modal manusia yang tinggi akan mampu menghasilkan ide-ide teknologi baru yang mampu mendorong peningkatan output.

\section{Penelitian Relevan}

a. David Kristianto, 2015, Sekolah Tinggi 
Ilmu Statistik, Jurusan Statistika Pengaruh Jumlah Penduduk, IPM, dan TPT terhadap Kemiskinan (Pendekatan Moneter dan Multidimensi) di Indonesia. Metode analisis yang digunakan adalah analisis deskriptif dan inferensia dengan menggunakan regresi data panel Data yang digunakan adalah data sekunder 33 provinsi yang ada di Indonesia periode 2012-2014. Hasil penelitian menunjukkan bahwa selama periode 2012-2014 indeks pembangunan manusia dan jumlah penduduk selalu meningkat, sementara tingkat kemiskinan dan tingkat pengangguran terbuka selalu menurun namun belum mencapai target RPJMN 20102014 dan SDGs. Jumlah penduduk berpengaruh signifikan dalam meningkatkan kemiskinan moneter, tetapi tidak berpengaruh signifikan dalam meningkatkan kemiskinan multidimensi. Indeks pembangunan manusia berpengaruh signifikan dalam menurunkan kemiskinan moneter dan multidimensi. Tingkat pengangguran terbuka tidak berpengaruh signifikan dalam meningkatkan kemiskinan moneter, tetapi berpengaruh signifikan dalam meningkatkan jumlah penduduk miskin multidimensi.

b. Dian Adi Wibowo, 2014, Universitas Negeri Yogyakarta, Indonesia, pengaruh pembiayaan pendidikan, tingkat pendidikan, pertumbuhan ekonomi dan kemiskinan di Jawa Tengah Penelitian ini bertujuan untuk mengetahui besarnya pengaruh pembiayaan pendidikan, tingkat pendidikan, pertumbuhan ekonomi secara parsial dan simultan terhadap tingkat kemiskinan Jawa Tengah periode 2002 2011. Penelitian ini merupakan penelitian ex post facto dengan pendekatan kuantitatif. Metode analisis yang digunakan adalah analisis data panel dengan pendekatan fixed effect method. Data diambil menggunakan teknik dokumentasi yang bersumber dari BPS dan lembaga pemerintahan terkait. Hasil penelitian menyimpulkan bahwa pembiayaan pendidikan, tingkat pendidikan dan pertumbuhan ekonomi berpengaruh negatif terhadap tingkat kemiskinan terhadap tingkat kemiskinan secara parsial dan simultan.

c. Fadlliyah Maulidah, 2015, Pengaruh Tingkat Pendidikan, Pendapatan Dan Konsumsi Terhadap Jumlah Penduduk Miskin di Provinsi Jawa Timur. Penelitian ini bertujuan untuk menganalisis pengaruh tingkat pendidikan, pendapatan dan konsumsi terhadap jumlah penduduk miskin di Provinsi Jawa Timur baik secara parsial maupun simultan. Populasi dalam penelitian ini adalah Provinsi Jawa Timur tahun 2009-2013. Teknik pengambilan sampel dengan teknik purposive sampling. Adapun metode pengumpulan data yang digunakan adalah metode dokumentasi. Sedangkan metode analisis menggunakan teknik analisis regresi data panel. Hasil analisis data menunjukkan bahwa secara parsial tingkat pendidikan tidak berpengaruh signifikan terhadap jumlah penduduk miskin Jawa Timur. Sedangkan pendapatan dan konsumsi berpengaruh signifikan terhadap jumlah penduduk miskin Jawa Timur. Sedangkan secara simultan tingkat pendidikan, pendapatan dan konsumsi berpengaruh signifikan terhadap jumlah penduduk miskin Jawa Timur.

\section{METODE PENELITIAN}

Penelitian ini terbatas pada pengujian sampai sejauh mana variabel tingkat pendidikan dan jumlah penduduk mempengaruhi variabel terikat yaitu variabel kemiskinan. Analisis dilakukan dengan menggunakan data tahunan selama 5 tahun, dari tahun 2011 sampai dengan tahun 2017. Data-data yang digunakan dalam penelitian ini adalah data sekunder yang diperoleh dari Badan Pusat Statistik (BPS) Kota Pekanbaru. 
Definisi operasional dalam penelitian ini adalah sebagai berikut :

1. Tingkat pendidikan: data pendidikan didapat melalui data dari Biro Pusat Statistik yaitu pendidikan yang ditamatkan penduduk pada 15 tahun ke atas dilihat pada tamatan SMA/MA dan sederajat karena pada hasil akhir pendidikan tersebut seseorang sudah siap untuk bekerja.

2. Jumlah penduduk: Data jumlah penduduk yang diukur dari jiwa.

3. Kemiskinan: Data kemiskinan yang digunakan bersumber dari Biro Pusat Statistik (BPS) didapat melalui data jumlah penduduk miskin kota, yang dinilai dari tingkat pendapatannya.

Analisis data dalam penelitian ini adalah deskriptif-kuantitatif terhadap data time series dan analisis kuantitatif. Analisis deskriptif-kualitatif disusun berdasarkan metode penelitian dengan pengujian terhadap data sekunder yang diperoleh dari berbagai sumber data, jurnal, artikel, buku, majalah, internet dan studi literatur ilmiah yang berkaitan dengan permasalahan yang sedang diteliti. Sedangkan untuk analisis kuantitatif digunakan alat bantu ekonometrika atau statistik untuk mendapatkan gambaran yang jelas tentang hubungan antara variabelvariabel yang digunakan dalam penelitian ini.

\section{Analisis Regresi}

Analisis regresi dalam penelitian ini adalah menggunakan regresi linier berganda, adapun bentuk persamaan regresi linier berganda dalam penelitian ini adalah :

$\mathrm{Y}=\mathrm{a}+\mathrm{b} 1 \mathrm{X} 1+\mathrm{b} 2 \mathrm{X} 2+\mathrm{e}$

Dimana:

$\mathrm{Y}$ : Tingkat Kemiskinan (Rp)

$\mathrm{X} 1$ : Tingkat Pendidikan (orang)

X2: Jumlah Penduduk (Jiwa)

a: konstanta;

b1, b2 : koefesien regresi

e : error/tingkat kesalahan

\section{HASIL DAN PEMBAHASAN}

\section{Deskriptif}

Tabel 3. Descriptive Statistics

\begin{tabular}{lccc}
\hline \multicolumn{3}{c}{ Descriptive Statistics } \\
& Mean & Std. Deviation & $\mathrm{N}$ \\
\hline $\begin{array}{l}\text { Tingkat } \\
\text { kemiskinan }\end{array}$ & $4.0743 \mathrm{E} 5$ & 35741.71264 & 6 \\
$\begin{array}{l}\text { Tingkat } \\
\text { pendidikan }\end{array}$ & $4.1179 \mathrm{E} 5$ & 46809.92931 & 6 \\
$\begin{array}{l}\text { Jumlah } \\
\text { penduduk }\end{array}$ & $1.0291 \mathrm{E} 6$ & 54874.79285 & 6 \\
\hline
\end{tabular}

Sumber : Hasil Penelitian, 2018

Berdasarkan tabel 3 di atas dapat dijelaskan bahwa nilai rata-rata untuk variabel Tingkat kemiskinan sebesar 4.0743, variabel Tingkat pendidikan sebesar 4.1179, dan variabel Jumlah penduduk sebesar 1.0291 .

\section{Interprestasi Model}

Interprestasi model digunakan untuk melihat arah hubungan yang dimiliki variabel terikat akibat dari perubahan dari variabel bebas. Berikut adalah hasil out put dari :

Tabel 4. Regresi Berganda

\begin{tabular}{lrr}
\hline & \multicolumn{2}{c}{ Unstandardized Coefficients } \\
Model & B & \multicolumn{1}{c}{ Std. Error } \\
\hline 1 (Constant) & -303479.404 & 110376.310 \\
& & \\
$\begin{array}{l}\text { Tingkat } \\
\text { pendidikan }\end{array}$ & .063 & .096 \\
$\quad \begin{array}{l}\text { Jumlah } \\
\text { penduduk }\end{array}$ & .665 & .082 \\
\hline
\end{tabular}

Sumber : Hasil Penelitian, 2018

Berdasarkan tabel di atas dapat diperoleh nilai persamaan regresi linier berganda yaitu:

$\mathrm{Y}=-303479.404+0.063 \mathrm{X} 1+0.665 \mathrm{X} 2$

Berdasarkan hasil persamaan dapat dijelaskan bahwa nilai -303479.404, memiliki arti bahwa jika variabel X1 dan X2 tetap, maka nilai varibel Y akan mengalami penurunan sebesar 303479.404 satuan. Nilai 
0.063X1, yaitu jika variabel X1 berubah satu satuan, maka variabel $\mathrm{Y}$ akan meningkat sebesar 0.063 satuan. Dan variabel X2 berubah satu satuan, maka variabel $\mathrm{Y}$ akan meningkat sebesar 0.665 satuan.

Berdasarkan hasil persamaan di atas dapat disimpulkan bahwa jika variabel X1 dan X2 memiliki nilai nol (0), maka variabel Y akan berkurang sebesar sate satuan.

\section{Uji signifikan secara parsial}

Uji parsial digunakan untuk melihat pngaruh yang signifika secara parsial, berikut adalah hasil out put uji signifikan secara parsial, yaitu sebagai berikut:

Tabel 5. Uji Signifikan Secara Parsial

\begin{tabular}{lrr} 
Model & \multicolumn{1}{c}{$\mathrm{t}$} & \multicolumn{1}{c}{ Sig. } \\
\hline 1 (Constant) & -2.749 & .071 \\
tingkat pendidikan & .657 & .558 \\
jumlah penduduk & 8.086 & .004 \\
\hline
\end{tabular}

Sumber : Hasil Penelitian, 2018

Berdasarkan tabel di atas, untuk tingkat pendidikan memiliki nilai Sig. $>0,05$ maka dapat disimpulkan bahwa variabel tingkat pendidikan (X1) tidak berpengaruh signifikan terhadap variabel tingkat kemiskinan (Y), sedangkan variabel jumlah penduduk memiliki nilai Sig. $<0,05$ maka dapat disimpulkan bahwa jumlah penduduk berpengaruh signifikan terhadap tingkat kemiskinan.

\section{Uji Signifikan Secara Bersama-Sama}

Dalam uji ini yaitu secara bersamasama apakah variabel bebas berpengaruh signifikan terhadap variabel terikat, berikut adalah hasil :

\begin{tabular}{|c|c|c|c|c|c|}
\hline \multirow{2}{*}{\multicolumn{2}{|c|}{ Model }} & \multicolumn{3}{|c|}{ Mean } & \multirow[b]{2}{*}{ Sig. } \\
\hline & & df & Square & $\mathrm{F}$ & \\
\hline \multirow[t]{3}{*}{1} & $\begin{array}{l}\text { Regres- } \\
\text { sion }\end{array}$ & 2 & $3.080 \mathrm{E} 9$ & $\begin{array}{r}40.72 \\
9\end{array}$ & $.007^{\mathrm{a}}$ \\
\hline & Residual & 3 & $7.563 \mathrm{E} 7$ & & \\
\hline & Total & 5 & & & \\
\hline
\end{tabular}

Sumber : Hasil Penelitian, 2018
Berdasarkan tabel di atas diperoleh nilai Sig. 0,007 < dari 0,05 maka dapat disimpulkan bahwa secara bersama-sama variabel bebas memiliki pengaruh yang signifikan terhadap variabel terikat.

\section{Uji Koefesien Determinasi}

Merupakan seberapa baik model yang digunakan dalam suatu penelitian, berikut adalah hasil penelitian mengenai koefesien determinasi.

\begin{tabular}{|c|c|c|c|}
\hline Model & $\mathrm{R}$ & $\begin{array}{c}\mathrm{R} \\
\text { Square }\end{array}$ & Adjusted R Square \\
\hline 1 & $.982^{\mathrm{a}}$ & .964 & .941 \\
\hline
\end{tabular}

Sumber : Hasil Penelitian, 2018

Berdasarkan tabel di atas diperoleh nilai R_Square sebesar 0,964 maka dapat disimpulkan bahwa kemampuan model merangkan sebesar 96,4 persen.

\section{PEMBAHASAN}

\section{Pengaruh tingkat pendidikan terhadap tingkat kemiskinan}

Berdasarkan hasil penelitian diperoleh bahwa tingkat pendidikan tidak berpengaruh signifikan terhadap tingkat kemiskinan, penelitian ini didukung oleh hasil penelitian yang dilakukan oleh Fadlliyah Maulidah, 2015, judul Pengaruh Tingkat Pendidikan, Pendapatan dan Konsumsi Terhadap Jumlah Penduduk Miskin di Provinsi Jawa Timur, bahwa secara parsial tingkat pendidikan tidak berpengaruh signifikan terhadap jumlah penduduk miskin Jawa Timur.

Tidak berpengaruhnya tingkat pendidikan dalam hal ini bahwa tingkat pendidikan yang tinggi tidak akan bisa menjamin mengurangi jumlah penduduk miskin.

\section{Pengaruh Jumlah Penduduk terhadap tingkat kemiskinan}

Berdasarkan hasil penelitian diperoleh bahwa jumlah penduduk berpengaruh signifikan terhadap tingkat kemiskinan. Penelitian ini sejalan dengan penelitian yang dilakukan oleh David Kristianto, 2015, 
Sekolah Tinggi Ilmu Statistik, Jumlah penduduk berpengaruh signifikan dalam meningkatkan kemiskinan moneter. Sesuai dengan pendapat aliran Malthusin terjadi ketidakseimbangan antara pertumbuhan penduduk berjalan berdasarkan deret ukur, sedangkan pertumbuhan/pertambahan makanan berdasarkan deret hitung. Artinya semakin bertambah jumlah penduduk maka pengeluaran pemerintah akan bertambah sehingga konsumsi masyarakat akan meningkat, daya beli meningkat maka akan mengakibatkan kelangkaan harga sehingga daya beli masyarakat akan berkurang lalu akan mengurangi tingkat pendapatan sehingga akan berdampak pada meningkatnya jumlah penduduk miskin.

\section{PENUTUP}

\section{Simpulan}

Simpulan dari penelitian ini adalah sebagai berikut:

1. Variabel yang berpengaruh signifikan secara parsal adalah variabel jumlah penduduk, secara bersama-sama variabel bebas berpengaruh signifikan terhadap variabel terikat.

2. Besarnya kontribusi yang diberikan variabel bebas terhadap variabel terikat adalah sebesar $96,4 \%$.

\section{Saran}

1. Untuk pemerintah agar lebih berkoordinasi kepada perusahaan swasta untuk membuka lapangan kerja, terutama untuk tingkat SLTA dan Sarjana. Juga menekan laju pertumbuhan jumlah penduduk, karena setiap tahunnya saja jumlah penduduk cepat meningkat sementara lapangan kerja tidak tersedia sehingga akan terjadi pengangguran yang besar.

2. Saran untuk peneliti berikutnya adalah perlu memasukan variabel lain, yaitu seperti PDRB, Investasi, dan inflasi.

\section{DAFTAR PUSTAKA}

BPS Kota Pekanbaru, 2017.

Fadlliyah Maulidah, 2015, Pengaruh Tingkat Pendidikan, Pendapatan dan Konsumsi Terhadap Jumlah Penduduk Miskin di Provinsi Jawa Timur Jurnal Ekonomi Pendidikan dan Kewirausahaan Vol. 3. No. 1, Tahun 2015.

Dian Adi Wibowo, 2014. Pengaruh Pembiayaan Pendidikan, Tingkat Pendidikan, Pertumbuhan Ekonomi dan Kemiskinan di Jawa Tengah, Jurnal Economia, Volume 10, Nomor 2, Oktober 2014.

David Kristianto, 2015, Pengaruh Jumlah Penduduk, IPM, dan TPT terhadap Kemiskinan (Pendekatan Moneter dan Multidimensi) di Indonesia.

UU RI No. 20 Tahun 2003 Andy, 2012: http;//fourseasonnew.blogspot.com)

Abuddin Nata, 2001. Pemikiran Para Tokoh Pendidikan Islam. PT. Raja Grafindo Persada, Jakarta.

Hakim, Abdul, 2006, Reformasi dan Pertanggungjawaban Keuangan Daerah. Yogyakarta, Fakultas Ekonomi UGM.

Hamid, 2008, Perekonomian Indonesia Masalah dan Kebijakan Kontemporer. UII Press, Yogyakarta.

Suryawati, 2004, Teori Ekonomi Mikro, UPP, AMP, YKPN, Yogyakarta.

Tirtarahardja. 2005, Pengantar Pendidikan, Rineka Cipta.

Notoatmodjo, 2010, Metode Penelitian Kesehatan. Jakarta: Rineka Cipta.

Badan Pusat Statistik Jakarta, 2011, Pedoman Pendataan Survei Sosial Ekonomi Nasional, Jakarta Pusat. 